\title{
EVALUASI PREMI JOINT LIFE PASANGAN SUAMI ISTRI MENGGUNAKAN COPULA FRANK
}

\author{
I Nyoman Widana ${ }^{1} \S$ dan Ni Made Asih ${ }^{2}$ \\ ${ }^{1}$ Jurusan Matematika, FMIPA - Universitas Udayana [Email: nwidana@yahoo.com] \\ ${ }^{2}$ Jurusan Matematika, FMIPA - Universitas Udayana [Email: madeasih@unud.ac.id] \\ $\S$ Corresponding Author
}

\begin{abstract}
This paper introduces the joint life satatus for married couples with independent and dependent mortality models. Using Frank copula and Indonesia Life Tables 2011, we evaluate the impact of dependent future lifetimes on the net single and level premium. The results show premium rates are reduced if models of dependent future lifetime are used compared to the models using an assumption of independence.
\end{abstract}

Keywords: Copula, Dependent, Mortality, Premium.

\section{PENDAHULUAN}

Masing-masing orang membuat rencana dan berharap perjalanan hidupnya mengikuti rencana yang telah dibuatnya. Tetapi pengalaman mengajarkan, rencana itu berkembang menjadi tak menentu. Kadang-kadang pembuat rencana menjadi frustasi, sebab mereka membuat asumsi yang tidak realistis. Asuransi didesain untuk mengatasi masalah-masalah keuangan yang timbul akibat dari kejadian-kejadian acak yang menggangu rencana yang telah dibuat. Misalkan meninggalnya kepala kelaurga sebagai pencari nafkah bagi keluarganya [1].

Saat ini perusahaan asuransi tidak hanya menyediakan produk untuk status hidup perorangan, tetapi juga untuk status gabungan (joint status). Contohnya, asuransi untuk pasangan suami istri. Misalkan benefit dibayarkan jika keduanya meninggal (pada kematian yang kedua) maka disebut asuransi last survivor . Sedangkan untuk benefi yang diberikan jika ada yang pertama kali meninggal (pada kematian yang pertama) maka disebut asuransi joint life.

Matvejevs [5] telah menghitung nilai premi untuk auransi joint life dan last survivor dengan menggunakan asumsi bahwa sisa usia dari pasangan suami istri adalah saling independen. Asumsi ini juga digunakan oleh [6] untuk menentukan besar premi untuk polis asuransi bersama. Disisi lain [4] mengevaluasi premi last survivor pasangan suami istri dengan menggunakan Metode Copula Frank. Perlu diperhatikan bahwa, untuk asuransi joint life dengan pesertanya adalah pasangan suami istri, mereka cendrung mengalami resiko yang sama terhadap hal-hal berikut: Stress Cardiomyopathy untuk pasangan suami istri dengan usia 55 tahun ke atas, kecelakaan yang dialami bersama, dan penyakit menular [4]. Hal ini berarti bahwa sisa usia dari pasangan suami istri ini tidak lagi saling independen atau dengan kata lain sisa usianya saling dependen. Tetapi, perusahan asuransi, dalam perhitungan preminya, untuk keperluan praktis, mengasumsikan sisa usia dari pasangan suami istri adalah independen. Hal ini mungkin kurang tepat. Sehingga, pada penelitian ini penulis ingin mengetahui bagaimana menentukan harga premi asuransi jiwa joint life dari pasangan suami istri yang kematiannya dependen. Selain itu ingin juga dilihat pengaruh keindependenan terhadap harga premi.

\section{METODE PENELITIAN}

\subsection{Status Joint Life}

$$
\text { Status yang berlangsung }
$$

sepanjang semua anggota masih tetap 
hidup dan berakhir jika ada anggota meninggal, dikenal dengan nama status joint life. Status ini dinyatakan oleh $\left(x_{1} x_{2} \cdots x_{m}\right)$ dengan $x_{i}$ menyatakan usia dari anggota grup yang ke $i$ dan $m$ menyatakan jumlah anggota grup. Selanjutnya nyatakan variabel random $T$ sebagai waktu sampai status joint life berakhir (time until failure of a status). Sehingga

$$
T=\min \left[T\left(x_{1}\right), T\left(x_{2}\right), \cdots, T\left(x_{m}\right)\right]
$$

dengan $T\left(x_{i}\right)$ menyatakan sisa usia dari $\left(x_{i}\right)[1]$.

Untuk kasus $x_{1}=x$ dan $x_{2}=y$ maka

$$
\begin{aligned}
F_{T}(t) & =\operatorname{Pr}(T \leq t)=\operatorname{Pr}(\min [T(x), T(y)]) \\
& =1-\operatorname{Pr}(T(x)>t \operatorname{dan} T(y)>t)
\end{aligned}
$$

Jika sisa usia dari ( $x)$ dan $(y)$ saling bebas maka

$$
\begin{aligned}
F_{T}(t) & =1-\operatorname{Pr}(T(x)>t) \operatorname{Pr}(T(y)>t) \\
& =1-{ }_{t} p_{x}{ }_{t} p_{y}=1-{ }_{t} p_{x y}
\end{aligned}
$$

dan peluang status joint life berakhir dalam selang waktu $[k, k+1]$ adalah

$$
\begin{aligned}
F_{T}(t)=\operatorname{Pr}(k< & T \leq k+1) \\
& =\operatorname{Pr}(T \leq k+1)-\operatorname{Pr}(T \\
& \leq k) \\
& ={ }_{k} p_{x y}-{ }_{k+1} p_{x y}
\end{aligned}
$$

\subsection{Copula Frank}

Perhatikan bentuk berikut ini

$$
F\left(x_{1}, x_{2}\right)=C\left(F_{1}\left(x_{1}\right), F_{2}\left(x_{2}\right)\right)
$$

$\mathrm{C}$ disebut fungsi Copula [3]. Mengingat bahwa

$$
\begin{aligned}
F\left(x_{1}, x_{2}\right)=\operatorname{Pr} & \left(X_{1} \leq x_{1}, Y_{1} \leq y_{1}\right) \\
& =1-\operatorname{Pr}\left(X_{1}>x_{1}\right) \\
& -\operatorname{Pr}\left(X_{2}>x_{2}\right) \\
& +\operatorname{Pr}\left(X_{1}>x_{1}, X_{2}>x_{2}\right)
\end{aligned}
$$

maka

$$
\operatorname{Pr}\left(X_{1}>x_{1}, X_{2}>x_{2}\right)=\operatorname{Pr}\left(X_{1}>x_{1}\right)+
$$$$
\operatorname{Pr}\left(X_{2}>x_{2}\right)-1+C\left(F_{1}\left(x_{1}\right), F_{2}\left(x_{2}\right)\right)
$$

Selanjutnya, ada banyak bentuk fungsi Copula, salah satunya adalah copula Frank yang mempunyai bentuk sebagai berikut [4]

$C(u, v)=\frac{1}{\theta} \ln \left[1-\frac{\left(1-e^{\theta u}\right)\left(1-e^{\theta v}\right)}{1-e^{\theta}}\right]$

dengan $\theta$ merupakan parameter yang menyatakan besarnya penyimpangan dari asumsi saling bebas.

\subsection{Anuitas Joint Life dan Asuransi Joint Live}

Nilai sekarang dari rangkaian pembayaran diawal tahun, selama $n$ tahun asalkan $(x)$ dan $(y)$ masih tetap hidup, disimbulkan dengan $\ddot{a}_{x y: \bar{n} \mid}$, serta dapat dituliskan dalam bentuk[1]

$$
\ddot{a}_{x y: \overline{n \mid}}=\sum_{t=0}^{n-1} v^{t}{ }_{t} p_{x y}
$$

Serupa dengan ini, perhatikan asuransi jiwa dengan benefit sebesar 1 yang dibayarkan diakhir tahun terjadinya kematian asalkan terjadi kematian salah satu di antara $(x)$ dan $(y)$. Nilai tunai dari asuransi ini adalah [2]

$A_{x y: \overline{n \mid}}^{1}=\sum_{t=0}^{n-1} v^{t+1}\left({ }_{t} p_{x y}-{ }_{t+1} p_{x y}\right)$

Besar premi ditentukan dengan menggunakan prinsip ekuivalensi dan mempunyai persamaan

$$
E[L]=0
$$

dengan besar kerugian pihak penanggung, $L$, sebagai variable random dari nilai tunai benefit dikurangi varibel random annuitas dari premi yang dibayarkan oleh pihak yang ditanggung [2].

\section{HASIL DAN PEMBAHASAN}

\subsection{Model Copula Frank dari Joint Life}

Berdasarkan (1) dan (2), peluang ( $x$ ) dan (y) $n$ tahun kemudian masih tetap hidup, dapat dinyatakan dalam bentuk

$$
\begin{gathered}
{ }_{n} p_{x y}={ }_{n} p_{x}+{ }_{n} p_{y}-1+ \\
\frac{1}{\alpha} \ln \left[1-\frac{\left(1-e^{\alpha}{ }_{n} q_{x}\right)\left(1-e^{\alpha} q_{y}\right)}{\left(1-e^{\alpha}\right)}\right]
\end{gathered}
$$


Dari (6) dan (3) diperoleh ekspektasi dari nilai tunai anuitasnya adalah

$$
\begin{aligned}
& \ddot{a}_{x y: \overline{n \mid}}=\sum_{k=0}^{n-1} v^{k}\left[{ }_{k} p_{x}+{ }_{k} p_{y}-1+\right. \\
& \left.\frac{1}{\alpha} \ln \left[1-\frac{\left(1-e^{\alpha_{k} q_{x}}\right)\left(1-e^{\alpha_{k} q_{y}}\right)}{\left(1-e^{\alpha}\right)}\right]\right]
\end{aligned}
$$

dan dari (6) dan (4)diperoleh ekspektasi nilai tunai benefitnya (besar premi tunggalnya) adalah $A_{x y: \bar{n} \mid}^{1}=$

$\sum_{k=0}^{n-1} v^{k+1}\left[{ }_{k} p_{x}-{ }_{k+1} p_{x}+{ }_{k} p_{y}-{ }_{k+1} p_{y}+\right.$

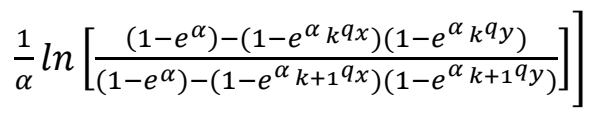

\subsection{Model Copula untuk Premi Joint Life}

Premi netto tahunan, $P$, dihitung dihitung dengan menggunakan (5)

$$
E[L]=0
$$

dengan

$$
\begin{gathered}
L=Z-P Y \\
Z=\left\{\begin{aligned}
v^{K_{x}+1}, & K_{x}<n-1 \\
0, & K_{x} \geq n,
\end{aligned}\right. \\
Y=\left\{\begin{aligned}
\ddot{a}_{\overline{K_{x}+1 \mid},} & K_{x}<n-1 \\
\ddot{a}_{\bar{n} \mid}, & K_{x} \geq n
\end{aligned}\right.
\end{gathered}
$$

atau

$$
P=\frac{E[Z]}{E[Y]}=\frac{A_{x y: \bar{n} \mid}^{1}}{\ddot{a}_{x y: \bar{n} \mid}}
$$

Selanjutnya dengan mengingat (7) dan (8) maka diperoleh

$$
\begin{aligned}
& P= \\
& \sum_{k=0}^{n-1} v^{k+1}\left[{ }_{k} p_{x}-{ }_{k+1} p_{x}+{ }_{k} p_{y}-{ }_{k+1} p_{y}+\frac{1}{\alpha} \ln \left[\frac{\left(1-e^{\alpha}\right)-\left(1-e^{\alpha}{ }_{k} q_{x}\right)\left(1-e^{\alpha}{ }_{k} q_{y}\right)}{\left(1-e^{\alpha}\right)-\left(1-e^{\alpha} k+1{ }^{q_{x}}\right)\left(1-e^{\alpha} k+1 q_{y}\right)}\right]\right. \\
& \sum_{k=0}^{n-1} v^{k}\left[{ }_{k} p_{x}+{ }_{k} p_{y}-1+\frac{1}{\alpha} \ln \left[1-\frac{\left(1-e^{\alpha}{ }_{k} q_{x}\right)\left(1-e^{\alpha}{ }_{k} q_{y}\right)}{\left(1-e^{\alpha}\right)}\right]\right]
\end{aligned}
$$

\section{Contoh Perhitungan}

Nilai tunai premi dari kontrak asuransi Joint life selama 10 tahun, dengan uang pertanggungan sebesar 100 juta rupiah untuk pasangan suami istri berusia berturut-turut 60 tahun dan 55 tahun, dapat dilihat pada Tabel 1. dengan nilai parameter $\alpha=-3,367,-3$, $-2,-1,0.00001$ dan suku bunga $6 \%$ per tahun.
Tabel 1. Nilai Tunai Premi

\begin{tabular}{|l|c|c|c|}
\hline$\alpha$ & $\ddot{a}_{6055: \overline{10 \mid}}$ & $A_{6055: \overline{10 \mid}}^{1}$ & Premi, $\mathrm{P}$ \\
\hline$-3,367$ & 7,040026 & 0,18826 & 2674136 \\
-3 & 7,033505 & 0,190437 & 2707574 \\
$-2,5$ & 7,024497 & 0,193496 & 2754588 \\
-2 & 7,015456 & 0,196627 & 2802767 \\
$-1,5$ & 7,00653 & 0,199782 & 2851368 \\
-1 & 6,997888 & 0,202903 & 2899482 \\
$-0,001$ & 6,982165 & 0,208774 & 2990105 \\
\hline
\end{tabular}

Dari Tabel 1. Terlihat bahwa jika $\alpha \rightarrow 0$ maka harga preminya akan mendekati harga premi dari pasangan suami istri dengan mortalitas saling independen.

Sedangkan, jika diasumsikan sisa usia dari pasangan suami istri saling independen maka harga preminya adalah

$$
\begin{aligned}
& P=\frac{10^{6} A_{6055: \overline{10 \mid}}^{1}}{\ddot{a}_{6055: \overline{10 \mid}}} \\
& =\frac{10^{6} A_{6055: 10 \mid}^{1} \sum_{t=0}^{9} v^{t+1}\left({ }_{t} p_{6055}-{ }_{t+1} p_{6055}\right)}{\sum_{t=0}^{n-1} v^{t}{ }_{t} p_{6055}} \\
& =2990190
\end{aligned}
$$

\section{SIMPULAN DAN SARAN}

Dalam penelitian ini, harga premi, untuk pasangan suami istri dengan asumsi sisa usianya saling dependen, lebih murah dibandingkan dengan harga preminya yang dihitung menggunakan asumsi independen.

Semakin kecil penyimpangannya dari asumsi saling bebas, maka harga preminya akan mendekati harga premi dari pasangan suami istri dengan sisa usia yang independen.

Pada penelitian ini digunakan suku bunga konstan, untuk penelitian selanjutnya disarankan untuk menggunakan suku bunga yang berubah secara stokastik

\section{Daftar Pustaka}

[1] N.L.Bowers, H.U. Gerber., J.C. Hickman, D.A. Jones, dan C.J. Nesbitt, Actuarial Mathematics. Schaumburg (DE): The Society of Actuaries, 1997. 
[2] D.C.M Dickson, M.R Hardy, dan H.R Waters, Actuarial Mathematics for Life Contingent Risks. Cambridge: Cambridge University Press, 2009

[3] P. Embretchts, Copulas: a Personal View. Ed ke-2, Zurich Switzerland,ETH 2009

[4] I. Fauziah. "Evaluasi Premi Polis last Survivor Pasangan Suami Istri Menggunakan Metode Copula Frank " Jurnal Cuchy Vol. 3 Nomor 1, 2013

[5] A. Matvejevs "Insurance Models for Joint Life and Last Survivor Benefit" Jurnal Informatica Vol. 12 Nomor 4, 2001

[6] L. E. Putra, "Penentuan Premi Untuk Polis Asuransi Bersama. " Jurnal Matematika UNAND Vol. 3 Nomor 1. 